\title{
Principal Investigator
}

National Cancer Institute

\section{Source}

National Cancer Institute. Principal Investigator. NCI Thesaurus. Code C19924.

An investigator who is responsible for all aspects of the conduct of a study. 